Syntax Fusion : Jurnal Nasional Indonesia

p-ISSN: -

e-ISSN : 2775-4440

Vol. 1, No. 7, Juli 2021

\title{
PENDEKATAN FILSAFAT SOSIAL EKONOMI PERSPEKTIF ISLAM DAN BARAT
}

\author{
Rahamat Nur Ramdan \\ UIN Sunan Gunung Djati Bandung \\ Email : ceprahmat49@gmail.com
}

\begin{abstract}
Abstrak
Filsafat ekonomi merupakan tema pembahsan kedudukan atau posisi seseorang dalam kelompok masyarakat yanga ditentukan oleh aktivitas ekonomi pendidikan serta pendapatan. Pada abad ke 20 dunia ditandai dengan perseteruan dua ideologi yang berpangkal kepada perbedaan sosial ekonomi yaitu sosialisme dan kapitalisme. Dua aliran tersebuat seiring dijadikan pembahsan paradigma. Didalam tulisan ini, melihat dua aliran tersebut dalam konteks yang sama, yaitu sebagai pemikiran yang lahir dari pandangan orang barat yang berbeda pandangan hidup uamat islam, sehingga tertarik untuk dikaji lebih dalam pendekatan filsafat sosial ekonomi dalam perspektif islam dan barat.
\end{abstract}

Kata Kunci: Filsafat sosial, filsafat islam, filsafat barat

\section{Pendahuluan}

Ilmu ekonomi dalam iklim akademis, masuk pada ranah ilmu praktis, karena dalam pembahasannya terkait usaha yanag dilakukan oleh manusia untuk memenuhi kebutuhannya, baik tingkat makro atau secara mikro (Alam S, 2013). Sehingga dalam pembelajaran ekonomi adalah membuat sebuah keputusan pada bidang pemasukan dan pengeluaran yang bersifat rasional, pengeluaran dalam segi rumah tangga, koperasi, perusahaan smapai negara. Semua merujuk pada kalkulasi ekonomi, agar pemasukan, pembelajaran terjadi seefektif mungkin.

Ilmu ekonomi yang berkaitan dengan ilmu kebijakan pengelauaran negara dipelajari dalam ekonomi pembangaunan, ilmu ekonomi yang pembahasanya pada masalah cash flow ( aliran/masuk keluar uang) dipelajari dalam ilmu akutansi. Sedangkan dalam permasalahan pengaturan usaha di pelajari dalam ilmu manjemen. Seiring dengan perkembanagan bank syariah muncul ilmu ekonomi islam atau ekonomi syariah. Tetapi sejauh ini perkembangan kajian ekonomi syariah belum berkembangan secara pesat atau luas maka belum banyak 
pemikir filsapat ekonomi yanag dikembangkan dari jurusan ekonomi (Wijaya Cuk Ananta, 2009).

Padahal dalam sejarah manusia, pernah ada konflik dua aliran besar, yaitu sosialisme dan liberalisme, kedua ini dipelajari oleh para ahli akademis dalam jurusan terkait, sehingga dipelajari secara, ontologis,epistemologi, ontologis. Maka mereka berhak mengembangkan usahanya mengunakan tenaga kerja dan berhak memiliki peralatan produksi. Sedangkan sosialisme mempunyai pandangan kultur berbeda bahwa, dalam iklim kebebasan kapitalisme berjouis terdapat kontradiksi soaial yaitu kontrakdiksi hubungan kerja, antar majikan dan budak/buruh (Damsar dan Indrayan, 2016).

Antara sosialisme dan kapitalisme, mempunyai sudut pandang yang sama. Mereka sama-sama lahir dari kultur barat. Maka sebagian para ahli menyebutkan bahwa kultur barat mempunyai perbedaan dengan islam. Yaitu pandangan hidup (word view). Jika islam pada umunya meletakan pandangan ke pada allah dan sedangkan barat perpedoman hal-halnya kepada pemahaman empiris (Muhamad Ismail, 2016). Dengan paparan latar belakang diatas maka tulisan ini akan membahasa Pendekatan Filsafat sosial Ekonomi Dalam Prsepektif Islam dan Barat.

\section{Metodologi}

Jenis penelitian ini adalah kajian pustaka,dimana sumber data di peroleh dari literatur kepustakaan. Baik bertupa buku, jurnal, hasil penelitian, atau sebagainya. Sedangkan metode yang diguinakan metode deskripsi (pengambaran) dan analisa (penguraian).

\section{Pembahasan}

Dalam literatur konteks ekonomi ada yang di sebut dengan filsafat ekonomi filsafat ekonomi yang berasal dari dua kata filsafat dan ekonomi. Berasal dari kata, philos dan sophos yang artinya mencintai kebijaksanaan. Ekonomi sendiri berasal dari bahasa yunani oikos dan nomos, kemudian mementuk kata oikonomia, yang artinya seni mengenlola rumah tangga (Abdullah Zaki, 2002). Saat ini, kehidupan ekonomi telah mnjadi standar kehidupan individu dan kolektif suatu nengara-bangsa. Keunggulan suatu negara diukur berdasarkan tingkat kemajuan ekonominya dan ukuran derajat keberhasilan menjadi sangat materialistik. Oleh karena itu ilmu ekonomi menjadi sangat penting bagi kehidupan suatu bangsa. Pakar ilmu ekonomi sekaliber marshal menyatakan bahwa kehidupan dunia ini dikendalikan oleh dua kekuatan besar, yaitu ekonomi dan keimanan agama (Marshal, 2012). Demikian juga, peradaban islam yang gemilang dimasa silam tidak mungkin terwujud tanpa dukungan kekuatan ekonomi dan ilmu ekonomi nya. Kini, kita perlu menggabungan kehidupan hidup manusia sebagimana diyatakan mrsalah untuk disatukan dalam upaya membangun pemikiran dan disiplin ekonomi islam dalam kerangka kerja pembangunan soaisal budaya dan politik. (Prajaja S Juhaya, 2012). 
Rahman mengemukakan bahwa filsafat sosial merupakan kajian dari filsafat yang mempelajari persoalan-persoalan prilaku sosial kemasyarakatan secar kerisis, radikal, dan lebih komprehensif (Rahman M. Tufiq, 2018). Dalam persoalan ini selaras dengan filsafat sosialisme yang dikemukanan oleh Harun bahwa Filsapat sosialisme tidak 'melirik' pada potensi tubuh, tetapi menempatkan hakekat manusia pada 'kerja' atau homo laboran. Sedangkan kapitalisme meujuk pada hakekat manusia dalam kebebasan dalam memenuhi kebutuhan hidupnya. Didalam perspektif islam, menempatkan hakekat tersebut terhubung dengan nikmat yang diberikan oleh allah. Dalam bahasa agama, allah berfiran dalam surat Ar Rahman : "Nikmat Allah apa lagi yang hendak kau dustakan?" disebut berulang-ulang dalam surat tersebut.

Berbeda dengan pemikiran Aristiteles, pemikiran Plato tentang ekonomi lebih berpengaruh sampai abad pertengahan. Berdagang dan pekerja keras pada masa ini, dianggap sebagai pekerjaan yang tidak layak. Sedangkan pekerjaan yang layak adalah filsuf, penyair dan seni (Bambang Q Anies, 2018). Pemikiran ini juga berpengaruh pada Neplatonisme, bahwa jiwa mempunyai tingkatan yang lebih tinggi dari pada materi (tubuh). Dampak dari filsapat ekonomi kehidupan transkasi barang dianggap hal yang buruk dan rendah menuju kesempurnaan hidup atau sosial.

Sebenarnya secara riil, ekonomi terkait dengan maslah sosiologi atau sosial, berdasrkan pemikiran manusia tidak dapat bertahan hidup engan mngandalkan dirinya sendiri dengan memanfaatkan lingkungan sekitarnya. Artinya dengan demikian manusia tidak bisa survaiv ketika kebutuhan yang kompleks, haruslah hidup ditengah masyarakat yang kompleks, dengan hal untuk menyandingkan aneka kebutuhan yang terpenuhi.

Dari pemikiran diatas maka organ tubuh lebih bergarga dan derajat paling tinggi nilainya sehingga tidak sebanding dengan nialai uang. Bahkan dengan kekayaan berlimpah tidak akan menjamin kebahgian jika kesehatanya terganggu. Pentingnya sebuh kesahatan maka penerpan dalam bidang kebijakan pemerintah adalah, negara harus memberikan jaminan kepada selaualauh rakyatnya, tidak hanya kepada lowongan pekerja, melainkan kebijakan kesehatan.

Secara epistemologi, islam menekankan pada aspek keterpaduan atara iman, ilmu dan amal perbuatan. Sebagai mana sabda nabi yang artinya : "Diyakinkan dengan hati, diucapkan dengan lisan dikerjakan dengan benar." (Hamdi Fahmy Zarkasyi, 2005). Sedangkan dalam keilmuan barat, ilmu pengetahuan tidak berhubungan dengan keyakinan atau persyahadatan. Mereka mngembangkan ilmu etika. Akan tetapi tidak berkaitan dengan ajalaran agama yang mereka anut (keristen). Ilmu dalam kategori Hebermas mempunyai tiga maksud kepentingan komunikasi kepentingan teknis -strategis, atau untuk keilmuan dalam rangka perubahan keilmuan prakxi. Hal ini bertolak belakang dalam islam, pengetahuan menentukan derajat seseorang dimata tuhannya.

Pandangan hidup seiring distilahkan dengan worldiew, yang meliputi segala sistem dalam kehidupan setiap manusia, baik itu politik, ekonomi, sosial maupun kebudayaan. 
Padndangannhidup dalam kehidupan sehari-hari seorang muslim diwujudkan keyakinan adanya allah, malaikat dan para nabi-nabinya setra aturan allah yang di sampikan kepada nabi yang sisebut dengan syariah. Keyakinan akan kebenaran islam diwujudkan dalam ekonomi seperti menjauhi riba dan rentenir, menghidari konsumsi barang yang diharamkan, tidak mengurangi takaran dalam perdagangan dan sebagainya.

Hal ini berpengaruh pada perpolitikan, seorang muslim cenderung menolak legalitas peroduk minuman keras, atau setidaknya membuat kebijakan mempersempit peredarannya. Hal ini akan berpengaruh pada dampak sosial generasi seorang muslim dan anak dibawah umur pada khususnya yang tergiur pada minuman keras bahkan epek sampingnya akan mengakibatkan mabuk. Kebijakan di bidang ekonomi pun berpengaruh, misalnya kebijakan pelepasan saham yang dimiliki oleh negara (pusat atau daerah) pada produk Minuman Keras.

Dibidang distribusi ekonomi, islam mempunyai persamaan dengan filsafat sosialisme. Dalam islam, terinspirasi daridari perintah untuk mencegah peredaran harta kekayaan diantara orang-orang kaya. Sedangkan dalam filsafat sosialisme terkait "sama rasa sama rata". Berkaitan dengan hal ini dalam filsafat sosialisme, untuk bagaimna mewujudkan 'sama rata sama rasa' dengan menghapus kepemilikan paktor produksi, sedangkan dalam islam, kebijakan pencegahan monofoli eredaran harta kekayaan, lewat peran negara, sebagaimana yang di contohkan oleh Nabi, yang mempunyai wewenang dalam pengaturan pembagian $F a$ ' $i$.

Antara islam dan sosialisme terdapat perbedaan ontologis. Kosep sosialisme (terwujud masyarakat yang sama rata dan sama rasa), berdasarkan pemikiran untuk mengembalikan manusia pada hakekatnya, kerja menghilakan keterasingan manusia. Sedangkan dalam islam, konsep pemerataan ekonomi, berdasar pada pemikiran bahwa bahwa itu perintah Allah, bahkan dilandasi dengan kaidah-kaidah islam, yaitu keadilan dan kepedulian terhadap kelompok lemah.

Pada akhirnya, meski ada perbedaan falsafah ekonomi yang sama antara islam dengan produk pemikiran yang dihasilkan paradigama pemikir barat, akan tetapi dihasilkan dari paradigma yang amat berlawanan. Maka perbedaan antara soislisme dan kapitalisme dari pemikiran paradigma barat sebenarnya mempunyai titik temu yang sama yaitu, bahwa ekonomi secara pemikiran paradigma berkaitan dengan maslah empiris. Artinya sosialisasi bersikap sangat saintis dan menganggap satu hal yang metafisis, sebagi masalah mistik yang berkaitan dengan perasaan manusia semata. 


\section{Kesimpulan}

Maka dengan pendekatan filsafat sosial Ekonomi perspektif islam dan barat dintandi perbedaan yang sanagat tajam yakni perbedaan antara soislisme dan kapitalisme dari pemikiran paradigma barat sebenarnya mempunyai titik temu yang sama yaitu, bahwa ekonomi secara pemikiran paradigma berkaitan dengan maslah empiris. Berladaskan keyakinan akan kebenaran islam diwujudkan dalam ekonomi seperti menjauhi riba dan rentenir, menghidari konsumsi barang yang diharamkan, tidak mengurangi takaran dalam perdagangan dan sebagainya. 
Alam S (2013) Ekonomi, Jakarta :Esisi

\section{Bibliografi}

Wijaya, Cuk Ananta (2009) Filsafat Adam Smith, vol.Vol.19.no.1. Jurnal Filsafat

Damsar, and indrayan, (2016) Pengantar sosiologi perdesaan, jakarta: kencana

Ismail, muhamad (2016) Menalar Makna Berpikir Dalam Al-Qur'an. Ponogoro : Unida Gontor Press Latif

Al Kaaf, Abdullah Zaki (2002) ekonomi dalam perspektif islam. Bandung Pustaka Setia.

Marshal dalam Pradja S.Juhaya. Ekonomi Syariah. (2012). Bandung: Pustaka Setia

Pradja S.Juhaya. Ekonomi Syariah. (2012). Bandung: Pustaka Setia

Rahman M. Tufiq (2018) Pengantar Filsafat Sosial, Bandung: LEKKS Hal.6.

Harun dalam Jurnal. Filsafat Ekonomi Islam dan Barat. STIE Semarang, 2018. Vol.10 No 3

Atholilah,Anton, and Bambang Q Anies, Sahifa. Dalam Jurnal. Filsafat Ekonomi Islam dan Barat. STIE Semarang.(2018). Vol.10.No 1.

Muheramtohadi Singgih, Jurnal STIE Semarang, Perbandingan Filsafat Ekonomi Islam dan Barat , 2018. Vol. vol. 10

Zarkasyi, Hamdi Fahmy (2005). 